\title{
The comparison between two age estimation methods based on human teeth
}

\author{
Elżbieta Żądzińska ${ }^{1}$, Andrea G. Drusini ${ }^{2}$, Nicola Carrara ${ }^{2}$ \\ ${ }^{1}$ Department of Anthropology, University of Łódź, Banacha 12/16, 90-237 \\ Łódź, Poland, E-mail: elzbietz@biol.uni.lodz.pl \\ ${ }^{2}$ Department of Biology, University of Padova, Via Bassi 58B, 35131 Padua, \\ Italy, E-mail: drusini@civ.bio.unipd.it
}

\begin{abstract}
From among age estimation procedures we chose two for comparison. One of them is the standard method based on root dentin transparency; the other one is based on coronal pulp cavity heigth. The material consisted of X-ray photographs and longitudinally sectioned teeth of 276 individuals (174 males and 102 females) of known age. The comparison shows that the poorly known TCI method is at least as precise as the most widely applied and acknowledged procedure based on longitudinal sections of teeth.
\end{abstract}

$K E Y$ WORDS teeth, ageing, coronal pulp cavity, root dentin transparency Prz. Antropol. - Anthropol. Rev. (2000), vol. 63, pp. 95-101, Figs. 5, Tables 2. ISBN 83-86969-60-1, ISSN 0033-2003

Teeth are very often used as a biological marker for human age determination. The most widely applied methods based on dental wear (e.g., ROSE \& UNGAR [1998]), cementum annulation counting (e.g. CHARLES et al. [1986]; RöSING \& KVAAL [1998]), root dentin transparency [DRUSINI et al. 1991; DRUSINI 1993] are rather time-consuming and in many cases require sophisticated laboratory equipment for preparing longitudinal sections of teeth. Other methods, based on the dynamics of tooth eruption process are limited to the short periods of ontogenesis. For permanent teeth this period covers about 7 years [JASWAL 1983; SMITH et al. 1994;
KACZMAREK 1995; GILLET 1997; HOLTGRAVE et al. 1997], but for deciduous dentition only about 20 months [SHUPER et al. 1985; SMITH \& GARN 1987; HOLMAN \& JONES 1998; ŻĄDZIŃSKA 1999].

The least known, but easily applied procedure of age estimation is based on secondary dentin deposition, clearly seen on dental radiographs, because with advancing age the size of the dental pulp cavity is reduced as a consequence of secondary dentin concrements [KVAAL et al. 1995; HILLSON 1996; BRAND \& ISSELHARD 1998; RÖSING \& KVAAL 1998]. This method has received but little attention in research, although the height 
of the coronal pulp cavity shows a significant correlation with chronological age [IKEDA et al. 1985; DRUSINI 1993; KVAAL et al. 1995; DRUSINI et al. 1997]. This correlation was especially high for female and male molars and ranged from -0.87 to -0.92 , respectively [DRUSINI et al. 1997].

The aim of this paper is to compare the age estimation method based on the coronal pulp cavity index (TCI) with the standard procedure of human age determination based on root dentin transparency (RDT).

\section{Materials and methods}

The material, consisting of X-ray photographs of intact teeth from 276 individuals (174 males, 102 females) of known age, was collected by A.G. Drusini during the years 1994-1995 from the Cittadella Civic Hospital (Padua) and four private dental clinics from the $\mathrm{Ve}$ neto region in northern Italy. On all photographs with a fully visible pulp cavity two following measurements were taken (Fig. 1): height of the crown $(\mathrm{CH})$ and height of the coronal pulp cavity (CPCH) [DRUSINI et al. 1997]. Then the tooth-coronal index (TCI) for each tooth was calculated as follows: $\mathrm{TCI}=\mathrm{CPCH}$ $x 100 / \mathrm{CH}$. The use of an index instead of absolute measurement excludes possible errors resulting from different scales of $\mathrm{X}$-ray photos [THANYAKARN et al. 1992a,b; DRUSINI et al. 1997]. In the study only the mandibular posterior teeth were considered (excluding the third molar) as suggested by DRUSINI et al. [1997]. Because the difference between the right and the left teeth is statistically insignificant in radiographic adult age determination [ITO 1972, 1975; IKEDA et. al. 1985; KULLMAN 1995; DRUSINI et al. 1997], the material was not divided according to body side. All measurements were taken using digital callipers to the nearest $.01 \mathrm{~mm}$.

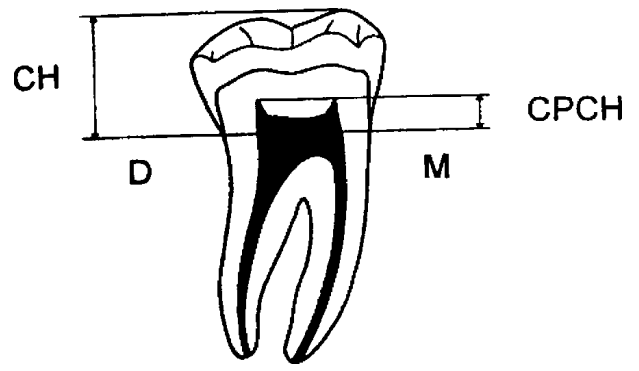

Fig. 1. Measurements taken off every studied panoramic radiograph. The line traced between the distal (D) and mesial (M) part of a tooth represents the division between the crown and root. $\mathrm{CH}$ - coronal height; $\mathrm{CPCH}-$ coronal pulp cavity height.

The comparative material, consisted of sectioned teeth of considered subjects with calculated root dentin transparency indices (RDT), was taken from the paper by DRUSINI et al. [1991]. Subsequently, for every individual the chronological age and the biological age estimated using both dental indices (TCI and RDT) were compared.

\section{Results and discussion}

The layers of secondary dentin are deposited in the pulp cavity successively during human life. More years of life mean more secondary dentin deposition and a smaller height of the coronal pulp cavity (Figs. 2, 3). The interdependence between calendar age and root dentin transparency is reverse. More years of life mean a higher level of translucent dentin in the root (Figs. 4, 5). 


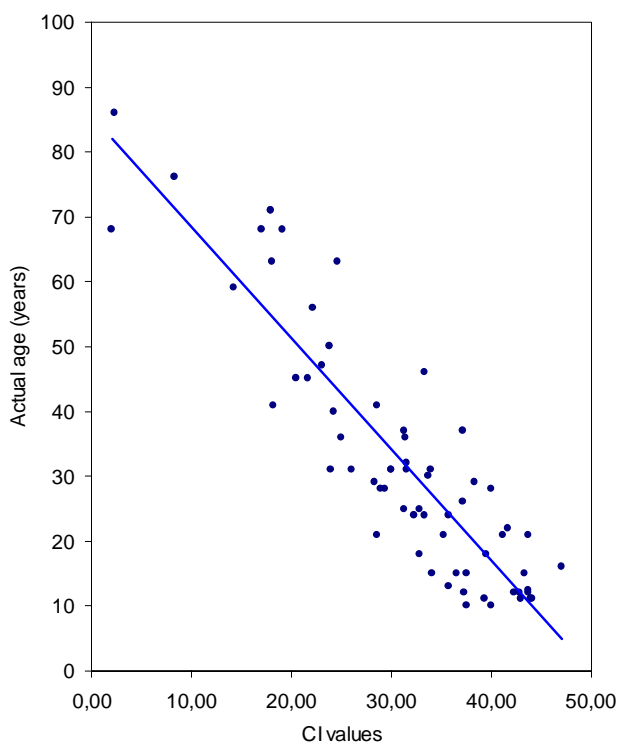

Fig. 2. Scatterplot and regression line of age on TC values for premolars (combined sample)

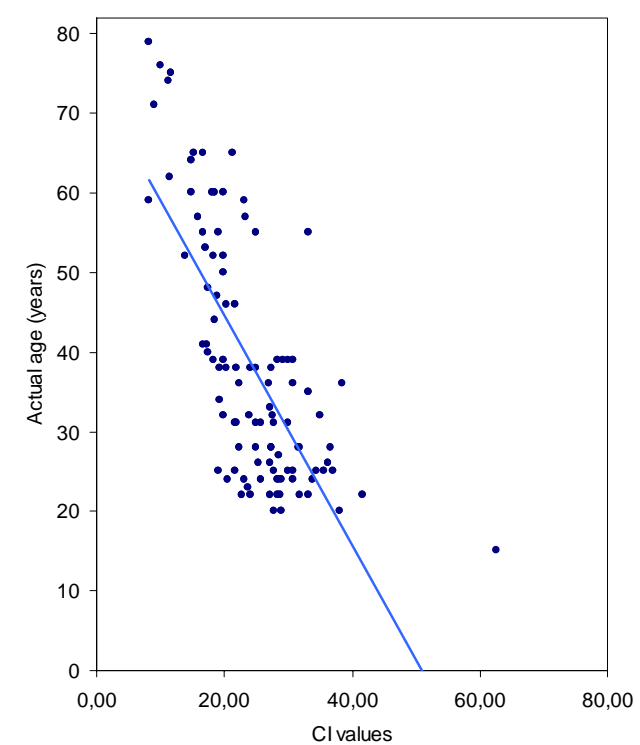

Fig. 3. Scatterplot and regression line of age on $\mathrm{TCl}$ values for molars (combined sample)

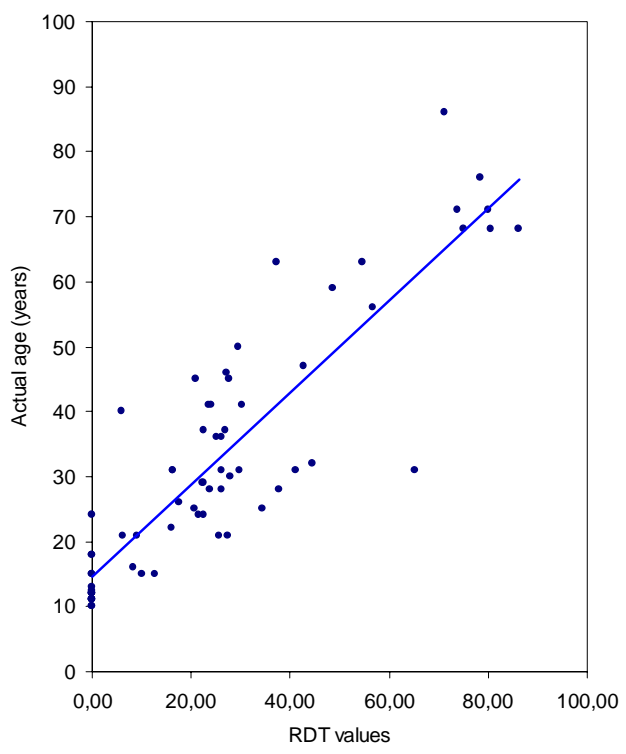

Fig. 4. Scatterplot and regression line of age on RDT values for premolars (combined sample)

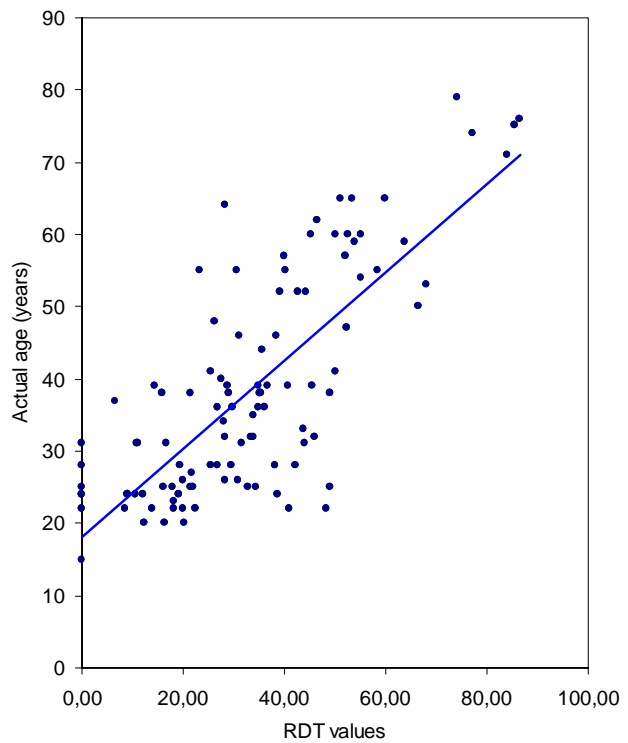

Fig. 5. Scatterplot and regression line of age on RDT values for molars (combined sample) 
The correlation coefficients between chronological age and the heigth of the coronal pulp cavity were very high and statistically significant $(p<0.01)$ both for premolars and molars, and oscillated for the mixed sample (of both sexes) from -0.894 to -0.718 respectively (Table 1 ). The highest value of this coefficient was observed for male premolars (-0.898). A high, statistically significant $(\mathrm{p}<0.01)$ correlation was also observed for the dependence between age and the degree of root dentin transparency. The values of correlation coefficients are similar to those cited before and reach for the mixed sample 0.885 for premolars and 0.766 for molars (Table 1). Using both methods, root dentin translucency and secondary dentin deposition, the premolars provide the highest coefficients of correlation between chronological age and the criteria of biological age considered in this paper.

Analysing the success of age estimation employing both procedures, we calculated their percentages of accuracy (Table 2). The differences between cal- endar and dental age ranged from \pm 5 to more than \pm 20 years. The highest percentages of success within \pm 5 years are received for premolars $(51.61 \%$ with RDT for females and $41.67 \%$ with $\mathrm{CPCH}$ for males). Considering the mixed sample (which is very important in forensic and archaeological material), the percentage of accuracy within \pm 5 years obtained was about $6 \%$ higher for premolars with the TCI method $(40.91 \%)$ than with the RDT method (34.33\%). Studying molars, the percentage of success is similar (33.01\% and $30.43 \%$ for RDT and $\mathrm{CPCH}$, respectively).

The TCI procedure gives higher percentage of accuracy within \pm 5 years. Nevertheless, we noticed more differences exceeding \pm 20 years for dental age estimated using this method. In some instances the rate of secondary dentin deposition increases in older adults with an inflection point at 35-40 years of age [WooDs et al. 1990]. This change of the pulp cavity size reduction rate could be an explanation of our results.

Table 1. Equations predicting age (Y) from the RDT and TCI methods by sex and type of tooth [DRUSINI et al. 1991, 1997]

\begin{tabular}{|c|c|c|c|c|c|}
\hline Method & Sex & $N$ & S.E. & $r$ & Prediction equation \\
\hline \multicolumn{6}{|c|}{ Premolars } \\
\hline $\begin{array}{l}\text { RDT } \\
\text { TCl }\end{array}$ & $\begin{array}{l}\mathrm{M} \\
\mathrm{M}\end{array}$ & $\begin{array}{l}36 \\
35\end{array}$ & $\begin{array}{l}9.34 \\
8.67\end{array}$ & $\begin{array}{l}0.8779 \\
-0.8984\end{array}$ & $\begin{array}{l}Y=21.9983+0.5361 X \\
Y=79.679-1.5356 X\end{array}$ \\
\hline $\begin{array}{l}\text { RDT } \\
\mathrm{TCl}\end{array}$ & $\begin{array}{l}F \\
F\end{array}$ & $\begin{array}{l}31 \\
31\end{array}$ & $\begin{array}{l}8.63 \\
9.04\end{array}$ & $\begin{array}{l}0.9003 \\
-0.8900\end{array}$ & $\begin{array}{l}Y=13.8100+0.7589 X \\
Y=75.523-1.3896 X\end{array}$ \\
\hline $\begin{array}{l}\mathrm{RDT} \\
\mathrm{TCl}\end{array}$ & $\begin{array}{l}M+F \\
M+F\end{array}$ & $\begin{array}{l}67 \\
66 \\
\end{array}$ & $\begin{array}{l}8.99 \\
8.72 \\
\end{array}$ & $\begin{array}{r}0.8855 \\
-0.8940 \\
\end{array}$ & $\begin{array}{l}Y=18.6745+0.6245 X \\
Y=77.617-1.4636 X\end{array}$ \\
\hline \multicolumn{6}{|c|}{ Molars } \\
\hline $\begin{array}{l}\text { RDT } \\
\mathrm{TCl}\end{array}$ & $\begin{array}{l}M \\
M\end{array}$ & $\begin{array}{l}138 \\
136\end{array}$ & $\begin{array}{l}10.50 \\
10.32\end{array}$ & $\begin{array}{l}0.7280 \\
-0.7414\end{array}$ & $\begin{array}{l}Y=18.6953+0.6184 X \\
Y=77.747-1.5066 X\end{array}$ \\
\hline $\begin{array}{l}\text { RDT } \\
\mathrm{TCl}\end{array}$ & $\begin{array}{l}\mathrm{F} \\
\mathrm{F}\end{array}$ & $\begin{array}{l}71 \\
71\end{array}$ & $\begin{array}{c}8.76 \\
11.63\end{array}$ & $\begin{array}{l}0.8286 \\
-0.6691\end{array}$ & $\begin{array}{l}Y=20.0360+0.5333 X \\
Y=73.846-1.3906 X\end{array}$ \\
\hline $\begin{array}{l}\text { RDT } \\
\text { TCl }\end{array}$ & $\begin{array}{l}M+F \\
M+F\end{array}$ & $\begin{array}{l}209 \\
207\end{array}$ & $\begin{array}{c}9.91 \\
10.77 \\
\end{array}$ & $\begin{array}{r}0.7663 \\
-0.7179 \\
\end{array}$ & $\begin{array}{l}Y=19.3490+0.5823 X \\
Y=76.073-1.4576 X\end{array}$ \\
\hline
\end{tabular}


Table 2. Percent of achievement of levels of accuracy in age prediction testing equations from the RDT and TCI methods

\begin{tabular}{|c|c|c|c|c|c|c|c|}
\hline \multirow[t]{2}{*}{ Teeth } & \multirow[t]{2}{*}{ Sample } & \multirow[t]{2}{*}{$\mathrm{N}$} & \multicolumn{5}{|c|}{ Percent in accuracy level (years) } \\
\hline & & & 5.0 & $5.1-10.0$ & $10.1-15.0$ & $15.1-20.0$ & $>20.0$ \\
\hline \multicolumn{8}{|c|}{ RDT } \\
\hline Premolars & $\begin{array}{l}\text { Male } \\
\text { Female } \\
\text { Combined }\end{array}$ & $\begin{array}{l}36 \\
31 \\
67\end{array}$ & $\begin{array}{l}27.78 \\
51.61 \\
34.33\end{array}$ & $\begin{array}{l}41.67 \\
22.58 \\
44.78\end{array}$ & $\begin{array}{l}19.44 \\
16.13 \\
14.93\end{array}$ & $\begin{array}{l}5.56 \\
9.68 \\
2.99\end{array}$ & $\begin{array}{l}5.56 \\
0.00 \\
2.99\end{array}$ \\
\hline Molars & $\begin{array}{l}\text { Male } \\
\text { Female } \\
\text { Combined }\end{array}$ & $\begin{array}{c}174 \\
71 \\
209 \\
\end{array}$ & $\begin{array}{l}31.03 \\
42.25 \\
33.01 \\
\end{array}$ & $\begin{array}{l}39.08 \\
26.76 \\
38.28 \\
\end{array}$ & $\begin{array}{l}18.39 \\
16.90 \\
17.70 \\
\end{array}$ & $\begin{array}{c}4.60 \\
14.08 \\
5.74 \\
\end{array}$ & $\begin{array}{l}6.32 \\
0.00 \\
4.78 \\
\end{array}$ \\
\hline \multicolumn{8}{|c|}{$\mathrm{TCl}$} \\
\hline Premolars & $\begin{array}{l}\text { Male } \\
\text { Female } \\
\text { Combined }\end{array}$ & $\begin{array}{l}36 \\
31 \\
66\end{array}$ & $\begin{array}{l}41.67 \\
35.48 \\
40.91\end{array}$ & $\begin{array}{l}30.56 \\
35.48 \\
25.76\end{array}$ & $\begin{array}{l}19.44 \\
19.35 \\
24.24\end{array}$ & $\begin{array}{l}2.78 \\
3.23 \\
7.58\end{array}$ & $\begin{array}{l}5.56 \\
6.45 \\
1.52\end{array}$ \\
\hline Molars & $\begin{array}{l}\text { Male } \\
\text { Female } \\
\text { Combined }\end{array}$ & $\begin{array}{c}138 \\
71 \\
207\end{array}$ & $\begin{array}{l}34.06 \\
22.54 \\
30.43\end{array}$ & $\begin{array}{l}23.91 \\
30.99 \\
28.02\end{array}$ & $\begin{array}{l}30.43 \\
22.54 \\
25.60\end{array}$ & $\begin{array}{c}4.35 \\
14.08 \\
9.66\end{array}$ & $\begin{array}{l}7.25 \\
7.04 \\
5.31\end{array}$ \\
\hline
\end{tabular}

The exactitude of age determination based on dental X-ray photographs is as precise as the most widely applied and acknowledged procedure based on longitudinal sections of teeth. This accuracy is similar for historical and contemporary living populations [DRUSINI et al. 1997], while SENGUPTA et al. [1999] found that the percentage length of the translucent zone in the root dentin in sectioned teeth is well correlated with chronological age only in the modern samples but not in the archaeological ones.

The TCI method has also another important advantage over the RDT analysis, since the scientists who apply it do not need extracted and sectioned teeth, the method can easily be used in living people. The X-ray diagnosis of jaws is the standard, non-invasive procedure during normal orthodontic therapy. That is why this method of age assessment could also be helpful in population anthropology, pediatry and pedodonty, where permanent observation of the interrelation between biological and calendar age is very valuable.

\section{References}

BRAND R.W., D.E. IsSELhard, 1998, Anatomy of orofacial structures, Mosby Inc., St. Louis

Charles D.K., K. Condon, J.M. Cheverud, J.E. Buikstra, 1986, Cementum annulation and age determination in Homo sapiens. I. Tooth variability and observer error, Am. J. Phys. Anthropol., 71, 311-320

Drusini A.G., 1993, Age estimation from X-ray findings, Anthrop. Anz., 51, 41-46

Drusini A.G., I. Calliari, A. Volpe, 1991, Root dentine transparency: age determination of human teeth using computerised densitometric analysis, Am. J. Phys. Anthropol., 85, 25-30

Drusini A.G., O. Toso, C. RanZATO, 1997, The coronal pulp cavity index: a biomarker for age determination in human adults, Am. J. Phys. Anthropol., 103, 353-363

GiLlet R.M., 1997, Dental emergence among urban Zambian school children: an assessment of the accuracy of three methods in assigning ages, Am. J. Phys. Anthropol., 102, 447-454

Hillson S., 1996, Dental anthropology, Cambridge University Press, Cambridge

Holman D.J., R.E. Jones, 1998, Longitudinal analysis of deciduous tooth emergence: I. Parametric survival analysis in Bangladeshi, Guatemalan, Japanese, and Javanese children, Am. J. Phys. Anthropol., 105, 209-230 
Holtgrave E.A., R. Kretschmer, R. Müller, 1997, Acceleration in dental development: fact or fiction, Eur. J. Othod., 19, 703-710

IKeda N., K. Umetsu, S. KashimuRa, T. SUZUKI, M. OuMI, 1985, Estimation of age from teeth with their soft X-ray findings, Jpn. J. For. Med., 39, 244-250

Iто S., 1972, Research on age estimation based on teeth, Jpn. J. Legal Med., 26, 31-41

Iто S., 1975, Age estimation based on tooth crowns, Int. J. Forensic Dent., 3, 9-14

JASWAL S., 1983, Age and sequence of permanent tooth emergence among Khasis, Am. J. Phys. Anthropol., 62, 177-186

KaczMAReK M., 1995, Poznańskie badania dtugofalowe. Wzorce i dynamika wyrzynania się zębów statych a ocena dojrzatości biologicznej organizmu, Przegląd Antrop., 58, 9-13

Kullman L., 1995, Accuracy and precision in some dental radiographic methods. A methodological study with special considerations in age estimation in juveniles, Swed. Dent. J., Suppl. 104, pp. 39

KvaAl S.I., K.M. Kolltveit, I.O. Thomsen, T. SolHeIM, 1995, Age estimation of adults from dental radiographs, Forensic Sci. Int., 74, 175-185

Rose J.C., P.S. Ungar, 1998, Gross dental wear and dental microwear in historical perspective, [in:] Dental Anthropology. Fundamentals, limits, and prospects, Springer Verlag, Wien, pp. 349-386

RÖSING F.W., S.I. KVAAL, 1998, Dental age in adults - a review of estimation methods, [in:] Dental Anthropology. Fundamentals, limits, and prospects, Springer Verlag, Wien, pp. 443-468

Sengupta A., D.K. WhitTAKer, R.P. Shellis, 1999, Difficulties in estimating age using root dentine translucency in human teeth of varying antiquity, Arch. Oral. Biol., 44, 889-899

Shuper A., H. Sarnat, F. Mimouni, M. MiMOUNI, I. VARSANO, 1985, Deciduous teeth eruption in Israeli children. A cross - sectional study, Clin. Pediatr. (Phila), 24, 342-344

Smith B.H., T.L. CRUmmet, K.L. BRANDT, 1994, Ages of eruption of primate teeth: a compendium for ageing individuals and comparing life histories, Yearb. Phys. Anthrop., 37, 177231

SMith B.H., S.M. GARN, 1987, Polymorphisms in eruption sequence of permanent teeth in American children, Am. J. Phys. Anthropol., 74, 289-303

THANYAKARN C., K. HANSEN, M. Rohlin, 1992, Measurements of tooth length in panoramic radiographs. 2. Observer performance, Dentomaxillofac. Radiol., 21, 31-35

Thanyakarn C., K. Hansen, M. Rohlin, L. ÅKESSON, 1992, Measurements of tooth length in panoramic radiographs. 1 . The use of indicators, Dentomaxillofac. Radiol., 21, 26-30

WoOdS M.A., Q.C. ROBINSON, E.F. HARRIS, 1990, Age-progressive changes in pulp widths and root lengths during adulthood: a study of American blacks and whites, Gerodontology, 9, 41-50

ŻĄDZIŃSKA E., 1999, Charakterystyka procesu pierwszego zabkowania jako wyznacznik wieku biologicznego dzieci łódzkich, Praca doktorska, UŁ Łódź

\section{Streszczenie}

Uzębienie ludzkie wykorzystywane jest bardzo często jako biologiczny wyznacznik wieku osobniczego człowieka. Najczęściej stosowane metody, służące takiej ocenie, oparte na stopniu starcia korony (m.in. ROSE \& UNGAR [1998]), akumulacji cementu korzeniowego (m.in. CHARLES i wsp. [1986]; RÖSING \& KVAAL [1998]), przeświecaniu zębiny korzenia [DRUSINI 1993; DRUSINI i wsp. 1991] są czasochłonne i zwykle wymagają zębów usuniętych z zębodołów oraz specjalnie spreparowanych. Inne procedury oparte na śledzeniu procesów dynamiki wyrzynania się zębów są ograniczone do krótkich etapów ontogenezy. W przypadku zębów stałych okres ten obejmuje około 7 lat, dla uzębienia mlecznego natomiast około 20 miesięcy. Metoda bazująca na odkładaniu się zębiny wtórnej w komorze korony zęba jest mało znana, choć łatwa w stosowaniu, gdyż zjawisko to jest doskonale widoczne na zdjęciach rentgenowskich. 
Celem tej pracy było porównanie na tej samej grupie osobników dwu metod oceny wieku zębowego: metody opartej na współczynniku wysokości komory miazgi zębowej (TCI) z metodą bazującą na stopniu przeświecania korzenia (RDT). Materiał stanowiły zdjęcia rentgenowskie zębów pochodzące od 276 osobników (174 mężczyzn i 102 kobiet) o znanym wieku kalendarzowym. Współczynniki wysokości komory miazgi zęba zostały wyliczone zgodnie z procedurą stosowaną przez DRUSINIEGO i wsp. [1997] dla wszystkich nieuszkodzonych zębów przedtrzonowych i trzonowych żuchwy [DRUSINI 1993; DRUSINI i wsp. 1997]. Dane dotyczące szlifów podłużnych zębów badanych osobników, z wyliczonymi współczynnikami przeświecania korzenia (RDT) pochodzą z wcześniejszej pracy DRUSINIEGO i wsp. [1991].

Wartości współczynników korelacji pomiędzy wiekiem chronologicznym a wysokością komory miazgi w koronie zęba były w badanym materiale bardzo wysokie i statystycznie istotne $(p<0,01)$, zarówno dla przedtrzonowców jak i zębów trzonowych i wynosiły w próbie mieszanej (złożonej z osobników płci męskiej i żeńskiej) odpowiednio od -0,894 do -0,718 (tab. 1). Podobnie wysoką, statystycznie istotną korelację zanotowano dla zależności pomiędzy wiekiem kalendarzowym a stopniem przeświecania korzenia. W celu przeanalizowania precyzji z jaka można oznaczyć wiek biologiczny używając obu procedur wyliczono dla nich procent dokładności (tab. 2). W grupie obupłciowej odsetki osobników, dla których różnica między wiekiem faktycznym a oszacowanym była nie większa niż \pm 5 lat, były podobne dla obu porównywanych metod.

Ocena wieku zębowego w oparciu wyłącznie o zdjęcia rentgenowskie szczęk jest więc co najmniej tak samo precyzyjna jak szeroko stosowana metoda oparta na szlifach podłużnych zębów. Ma ona przy tym tę przewagę nad analizą RDT, że może być wykorzystywana w badaniach współcześnie żyjących populacji ludzkich. Diagnoza przy użyciu zdjęć rentgenowskich szczęki jest standardową, nie inwazyjną procedurą stosowaną w trakcie terapii stomatologicznej i ortodontycznej, a zatem może być pomocna $\mathrm{w}$ antropologii populacyjnej, pediatrii i pedodoncji, gdzie ciągła obserwacja wzajemnych relacji pomiędzy wiekiem biologicznym a kalendarzowym jest niezwykle cenna. 